\title{
OBTENTION OF PROTEIN CONCENTRATE AND POLYPHENOLS FROM MACADAMIA (MACADAMIA INTEGRIFOLIA) WITH AQUEOUS EXTRACTION METHOD
}

\author{
LARA ${ }^{1}$, VILCACUNDO E ${ }^{2}$, CARRILLO $C^{1}$, CARPIO $C^{1}$, SILVA M $^{1}$, ALVAREZ ${ }^{1}$, CARRILLO W ${ }^{1 *}$
}

${ }^{1}$ Laboratory of Functional Foods, Faculty of Foods Science and Engineering, Technical University of Ambato, Av. Los Chasquis y Rio Payamino, Campus Huachi, CP 1801334, Ambato-Ecuador. ${ }^{2}$ Faculty of Health and Human Sciences, Bolivar State University, Academic Campus "Alpachaca" Av. Ernesto Che Guevara s/n y Av. Gabriel Secaira, EC. 020150, Guaranda, Ecuador. Email: wi.carrillo@uta.edu.ec

Received: 21 August 2016, Revised and Accepted: 17 October 2016

\section{ABSTRACT}

Objective: The aim of this study was to obtain protein concentrates from Macadamia using alkaline $\mathrm{pH}$ at different pHs of precipitation with water to analyze the protein isolates using the native-polyacrylamide gel electrophoresis (PAGE), sodium dodecyl sulfate-PAGE (SDS-PAGE) electrophoresis, and reversed-phase high-performance liquid chromatography (RP-UHPLC) methods.

Methods: Macadamia protein concentrates were obtained using the isoelectric precipitation method at different pHs using water as solvent. Proteins were analyzed using the native-PAGE, SDS-PAGE electrophoresis, and RP-UHPLC methods.

Results: A yield of $36.57 \pm 0.17^{\mathrm{a}}$ of protein concentrate of defatted Macadamia flour at $\mathrm{pH} 6.0$ with a $51.564 \%$ of protein was obtained using the Dumas method. Polypeptides profile was identified in the 11-63 kDa range. Total polyphenols content was high at pH 5.0 with a value of $367,340 \mathrm{mg}$ gallic acid equivalent equivalents $/ 100 \mathrm{~g}$.

Conclusions: Macadamia seed is a good source of proteins. Native-PAGE, SDS-PAGE, and RP-UHPLC are good methods to identify the Macadamia protein isolate in the presence of water.

Keywords: Macadamia protein concentrate, Polyphenols, Sodium dodecyl sulfate-polyacrylamide gel electrophoresis, Reversed-phase high-performance liquid chromatography.

(C) 2017 The Authors. Published by Innovare Academic Sciences Pvt Ltd. This is an open access article under the CC BY license (http://creativecommons. org/licenses/by/4. 0/) DOI: http://dx.doi.org/10.22159/ajpcr.2017.v10i2.14808

\section{INTRODUCTION}

Tree nuts are dry fruits with one seed, in which the ovary wall becomes hard at maturity. Usually, consumable tree nuts include almond, Brazil nut, cashew, hazelnut, Macadamia, pecan, pine nut, pistachio, and walnut; the consumer definition also includes peanut, which is botanically legume, but has a nutrient profile similar to those of tree nuts and it is thus identified as part of the nut food group [1-3].

Macadamia is a genus of flowering plants in the family Proteaceae and is cultivated for its edible kernels. There are four species of Macadamia, and all occur in subtropical rainforests along the East coast of Australia. Only two of the species, Macadamia integrifolia and Macadamia tetraphylla, generate edible nuts and are of commercial importance. M. integrifolia, commonly known as the smooth-shell Macadamia, provides kernels with higher quality, whereas $M$. tetraphylla, known as the rough-shell Macadamia, is more adaptable and can grow more easily at low temperatures or over a wider range of temperatures $[4,5]$. The other two species, Macadamia ternifolia and Macadamia jansenii, are inedible, as they contain cyanogenic glycosides which are toxic [6].

The Macadamia is the only Australian plant that has been domesticated on a commercial scale as a food crop. Macadamia is cultivated mainly in Australia, the USA (Hawai and California), and South Africa. There are also expanding industries in Brazil, Guatemala, and Kenya, and smaller industries in New Zealand, Malawi, Paraguay, Ecuador, and other countries [7-9]. The worldwide production of Macadamia sp. is approximately 44,000 metric tons (kernel), $86 \%$ of which come from Australia, South Africa, Kenya, the United States, and Malawi. Australia is the world's largest producer, with approximately 14,100 metric tons [10]. M. integrifolia contains approximately $70 \%$ of oil and its oil is the most highly monounsaturated fatty acids, which possibly help lower blood cholesterol, and reduce the risk of heart disease and also containing $7.9 \%$ of protein $[11,12]$. Its defatted flours contain between $30.40 \%$ and $36.45 \%$ of protein. The Macadamia kernel is a rich source of lipids, proteins, and important micronutrients. However, its chemical composition can vary considerably depending on the variety, seed maturity, location, and growth conditions [7]. The aim of this study was to obtain Macadamia protein concentrates using the isoelectric precipitation method and phenolic component using water as solvent.

\section{METHODS}

Protein concentrates from Macadamia nuts

Commercial Macadamia nuts (Rey Macadamia) were purchased at the supermarket in Ecuador. Macadamia protein concentrate was prepared according to Martiínez and Añón (1996) [13] with modifications. The defatted flour was suspended in water in a $1: 10 \mathrm{w} / \mathrm{v}$, and the suspension was adjusted at $\mathrm{pH} 8.0$ by adding $2 \mathrm{M} \mathrm{NaOH}$. The suspension was stirred during $1 \mathrm{hrs}$ and then centrifuged at $4500 \mathrm{~g}$ for 30 minutes at $25^{\circ} \mathrm{C}$. The supernatant was adjusted at $\mathrm{pHs} 2.0 ; \mathrm{pH} 3.0 ; \mathrm{pH} 4.0 ; \mathrm{pH} 5.0$, and $\mathrm{pH} 6.0$ with $2 \mathrm{NHCl}$ and centrifuged for 20 minutes at $4500 \mathrm{~g}$. The pellet was suspended in a small volume of water, neutralized with $0.1 \mathrm{M} \mathrm{NaOH}$, lyophilized and then frozen at $-20^{\circ} \mathrm{C}$. The content of protein isolate was determined using the Dumas method (VELP NDA 701 Dumas Nitrogen Analyzer). The factor used to calculate the percentage of protein was (\% Nx pf=\% PROT): 5.70 [14]. 
Sodium dodecyl sulfate-polyacrylamide gel electrophoresis (SDS-PAGE)

Native-PAGE and SDS-PAGE electrophoresis of Macadamia protein concentrates were carried out according to the method proposed by Laemmli (1970) [15] using 4-8\% and $4-12 \%$ polyacrylamide gel in a Mini-PROTEAN electrophoresis system (Bio-Rad, Hercules, CA, USA). Polypeptide bands were stained in Coomassie Brilliant Blue G-250 for 12 hrs. Relative molecular masses of protein were determined by a comparison to molecular weight markers (Bio-Rad, Hercules, CA, USA).

\section{Extraction of polyphenols}

After the precipitation of proteins from Macadamia using water at different $\mathrm{pHs}$, the supernatants were lyophilized during $48 \mathrm{~h}$. Then, the dry samples were stored at $-20^{\circ} \mathrm{C}$.

\section{Determination of total polyphenols}

Total phenolics in the obtained extracts were estimated by a colorimetric assay based on the procedures described by Singleton and Rossi (1965) [16] with some modifications. Briefly, $1 \mathrm{~mL}$ of sample was mixed with $1 \mathrm{~mL}$ of Folin and Ciocalteu's phenol reagent. After 3 minutes, $1 \mathrm{~mL}$ of saturated sodium carbonate solution was added to the mixture and adjusted to $10 \mathrm{~mL}$ with distilled water. The reaction was kept in the dark for 90 minutes. Then, the absorbance was read at $725 \mathrm{~nm}$ using a spectrophotometer (Thermo Scientific Evolution 200). Gallic acid was used for constructing the standard curve $(0-0.075 \mathrm{mg} / \mathrm{mL})$. The results were expressed as mg of gallic acid equivalents (GAEs)/100g of dried sample.

Analysis of concentrate Macadamia protein using reversed-phase high-performance liquid chromatography (RP-UHPLC)

All concentrate Macadamia proteins were analyzed using RP-UHPLC on Agilent 1200 infinity series UHPLC System (Agilent Technologies, Waldbronn, Germany). The variable wavelength detector was $280 \mathrm{~nm}$. The column used was EC C18 (Agilent Poroshell $120,4.6 \times 50 \mathrm{~mm} \times 2.7 \mu \mathrm{m}$ of particle size). Samples were eluted at $1.0 \mathrm{~mL} /$ minutes with a linear gradient from $0 \%$ to $70 \%$ of solvent B (acetonitrile and trifluoroacetic acid [TFA], 1000:0.270 v/v) in solvent A (water and TFA, 1000: $0.370 \mathrm{v} / \mathrm{v}$ ) during 10 minutes. The injection volume was $100 \mu \mathrm{L}$ for each duplicated sample.

\section{Statistical analysis}

Results are presented as means \pm standard deviation (SD) from the three replicates of each experiment. Differences between mean values were determined using the analysis of variance (ANOVA). The post-hoc analysis was performed with the Tukey's test. All tests were considered significant at $\mathrm{p}<0.05$. Statistical analyses were performed using the software package Prism 4 for Windows, version 4.3 (GraphPad Software Inc., www.graphpad.com).

\section{RESULTS}

Nuts of Macadamia were used to obtain the defatted flour of Macadamia. The defatted Macadamia flour was used to obtain Macadamia concentrate protein using the isoelectric precipitation method at different $\mathrm{pHs}(\mathrm{pH} 2.0 ; \mathrm{pH} 3.0 ; \mathrm{pH} 4.0$; $\mathrm{pH}$ 5.0, and $\mathrm{pH}$ 6.0) with water as solvent. The highest yield was obtained at $\mathrm{pH} 6.0$ with $36.57 \pm 0.17 \%$. Yields for $\mathrm{pH} 2.0$; $\mathrm{pH} 3.0$; $\mathrm{pH} 4.0$, and $\mathrm{pH} 6.0$ presented no statistical differences. Only at $\mathrm{pH} 5.0$, the treatment presented statistical differences with $\mathrm{p}<0.05$ (Table 1 ). The contents of protein in the Macadamia concentrates protein were analyzed using the Dumas method. The treatments at pH 3.0; pH 4.0; pH 5.0, and pH 6.0 presented a higher content of protein. The best treatment identified was at $\mathrm{pH} 5.0$ with a value of $52.962 \%$. At $\mathrm{pH} 4.0$ and $\mathrm{pH} 6.0$, there are no statistical differences with $\mathrm{p}<0.05$ (Table 1 ).

Values are expressed in grams per $100 \mathrm{~g}$ of protein. Values are means \pm SD of three determinations. Different letters show statistical differences between the groups $(\mathrm{p}<0.05)$ ANOVA and Tukey's test.

The profile proteins from Macadamia were analyzed using the electrophoresis native and SDS-PAGE methods.

\section{Native-PAGE}

In the gel of polyacrylamide, we can observe one band at all pHs assayed with molecular weight higher than $198 \mathrm{kDa}$. The gel shows bands between 6.5 and $41 \mathrm{kDa}$. These bands were strongly tinged with the solution Blue Coomassie (Fig. 1).

\section{SDS-PAGE}

In the presence of the reductor agent 2 - $\beta$-mercpatoethanol, the gel shows that at pHs 3.0; $\mathrm{pH} 4.0 ; \mathrm{pH} \mathrm{5.0,} \mathrm{and} \mathrm{at} \mathrm{pH} 6.0$, there are higher contents of proteins as all bands were strongly tinged with the solution of Blue Coomassie used in this assay. Two bands can also be observed, one corresponding at $50 \mathrm{kDa}$ approximately and the second one with a molecular weight of $45 \mathrm{kDa}$ approximately. These bands correspond to the globulin fraction from Macadamia. Two bands of $25 \mathrm{kDa}$ were identified as the albumin fraction of Macadamia. At pH 2.0, the bands were stained lower, and this result is in accordance with results of protein content obtained using the Dumas method (Fig. 2). The analysis of the SDS-PAGE electrophoresis method in the absence of the reductor agent (2- $\beta$-mercaptoethanol) shows two bands with higher intensity at $\mathrm{pH} 3.0 ; \mathrm{pH} 4.0$; $\mathrm{pH} 5.0$, and $\mathrm{pH}$ 6.0. Only at $\mathrm{pH} 2.0$, we can observe a lower intensity of these bands. The molecular weight of these bands ranges between 45 and $50 \mathrm{kDa}$. Moreover, it was possible to observe two bands with lower molecular weights of $25 \mathrm{kDa}$ (Fig. 3).

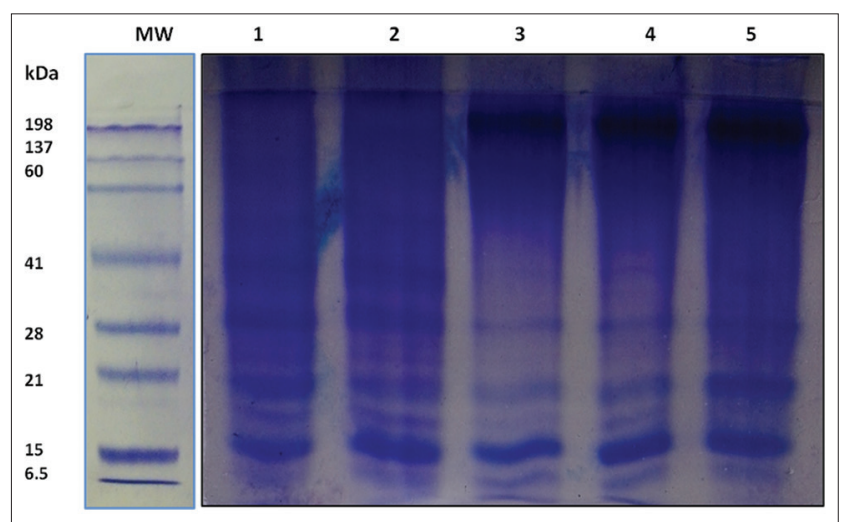

Fig. 1: Native-polyacrylamide gel electrophoresis of proteins from Macadamia. MW: Molecular weight. Lane 1: Concentrate of Macadamia obtained at pH 2.0; Lane 2: Concentrate of Macadamia obtained at pH 3.0; Lane 3: Concentrate of Macadamia obtained at pH 4.0; Lane 4: Concentrate of Macadamia obtained at pH 5.0 and Lane 5: Concentrate of Macadamia obtained at pH 6.0

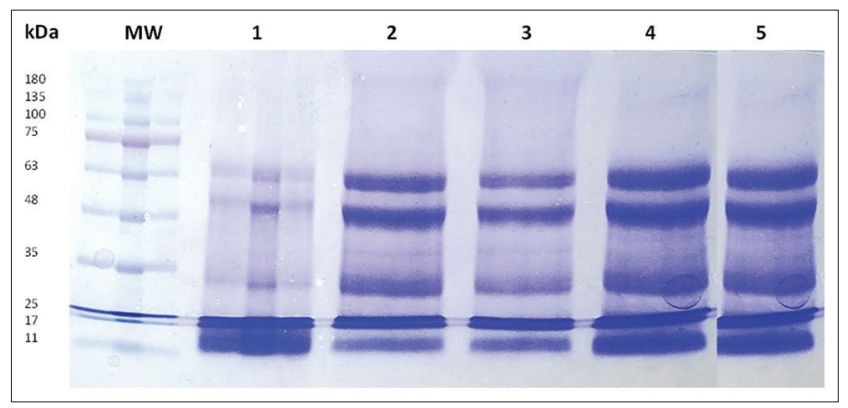

Fig. 2: Sodium dodecyl sulfate-polyacrylamide gel electrophoresis of proteins from Macadamia without the reductor agent (2- $\beta$-Mercaptoethanol). MW: Molecular weight; Lane 1: Concentrate of Macadamia obtained at pH 2.0; Lane 2: Concentrate of Macadamia obtained at pH 3.0 Lane 3: Concentrate of Macadamia obtained at pH 4.0; Lane 4: Concentrate of Macadamia obtained at pH 5.0 and Lane 5: Concentrate of Macadamia obtained at pH 6.0 


\section{RP-UHPLC}

All Macadamia protein concentrates were analyzed with the RP-UHPLC method during 12 minutes. The chromatograms show the profile of proteins obtained from Macadamia nuts. Fig. 4a and b show two peaks with high capacity of absorbance at $280 \mathrm{~nm}$ with low hydrophobicity. The peaks have the same time of retention. These proteins are acid proteins as proteins were obtained at low $\mathrm{pH}$ of precipitation. At pH 4.0; pH 5.0, and pH 6.0, the peaks present less intensity with $280 \mathrm{~nm}$ (Fig. 4c-e).

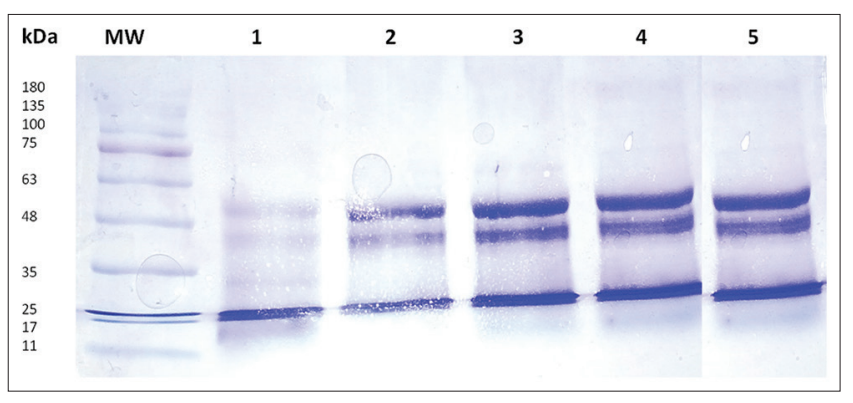

Fig. 3: Sodium dodecyl sulfate-polyacrylamide gel electrophoresis of proteins from Macadamia with the reductor agent (2- $\beta$-Mercaptoethanol). MW: Molecular weight; Lane 1: Concentrate of Macadamia obtained at pH 2.0; Lane 2: Concentrate of Macadamia obtained at pH 3.0;

Lane 3: Concentrate of Macadamia obtained at $\mathrm{pH}$ 4.0;

Lane 4: Concentrate of Macadamia obtained at pH 5.0 and Lane 5: Concentrate of Macadamia obtained at pH 6.0

\section{Content of polyphenols}

The content of polyphenols presents in the supernatant after separation of Macadamia concentrate protein was evaluated. The content of polyphenols was determined using a colorimetric assay with the Folin and Ciocalteu's phenol reagent. The highest content of polyphenols was obtained at $\mathrm{pH} 5.0$ with a value of $367,340 \mathrm{mg} \mathrm{GAE} / 100 \mathrm{~g}$ protein of sample. At $\mathrm{pH} 6.0$, the content was $289,150 \mathrm{mg}$ GAE/100 g protein sample. At acid pHs, the content values of polyphenols were low (Table 2).

Values are means \pm SD of three determinations. Different letters show a statistical difference between the groups $(<0.05)$ ANOVA and Tukey's test.

\section{DISCUSSION}

Protein concentrates are considered with a protein content of 35$80 \%$ on a dry basis. Protein isolates are defined to have protein content higher than $85 \%$. Whey protein concentrate and Whey protein isolate are used in the food industry to obtain pure proteins, hydrolysates, and ingredients in many foods such as the production of infant formula $[17,18]$. In this study, it was possible to obtain Macadamia protein concentrates at $\mathrm{pH}$ 3.0; $\mathrm{pH} 4.0 ; \mathrm{pH} 5.0$, and $\mathrm{pH}$ 6.0. Only at $\mathrm{pH} 2.0$, the Macadamia protein concentrate was difficult to obtain. The gel SDS-PAGE confirms that at $\mathrm{pH} 2.0$ bands were very little stained. The best treatment was at pH 5.0 with a value of $52.962 \%$ protein content on a dry basis using the Dumas method.

Legumins, vicilins, and $2 \mathrm{~S}$ albumins represent major seed storage of protein components of nuts. Vicilins, also called 7S globulins, comprise one well-known class of storage proteins and can constitute as much

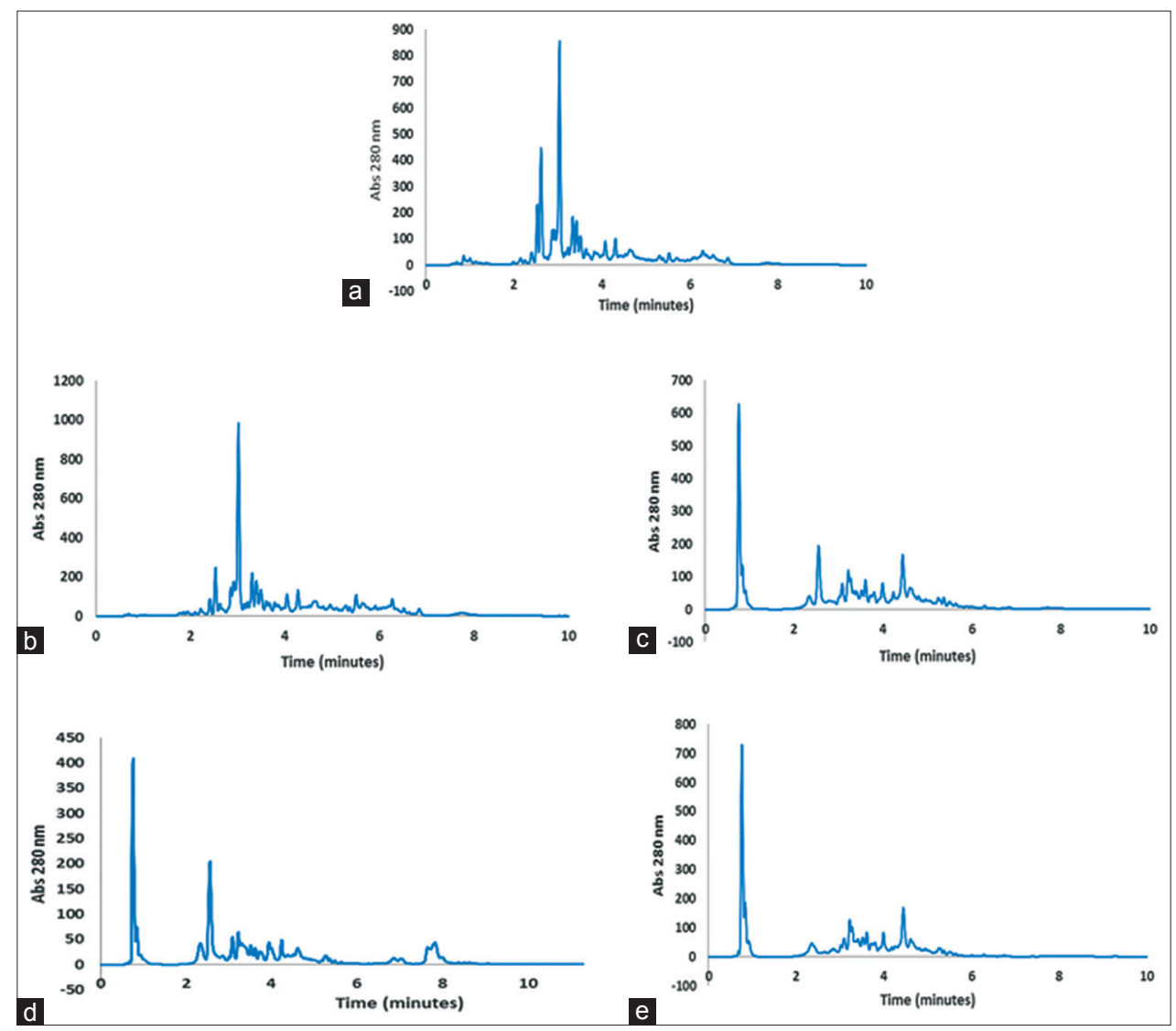

Fig. 4: Reversed-phase high-performance liquid chromatography of Macadamia protein concentrate obtained at different pHs. (a) Macadamia protein concentrate at $\mathrm{pH} 2.0$ (b) Macadamia protein concentrate at $\mathrm{pH} 3.0$ (c) Macadamia protein concentrate at pH 4.0 (d) Macadamia protein concentrate at pH 5.0 (d) Macadamia protein concentrate at pH 6.0. Column Zorbax EC C18 (Agilent Poroshell 120, $4.6 \times 50 \mathrm{~mm} \times 2.7 \mu \mathrm{m}$ of particle size) 
Table 1: Content of Macadamia protein concentrates obtained at different pHs and content of protein using the Dumas method

\begin{tabular}{lllll}
\hline Sample & pH 2.0 & pH 3.0 & pH 4.0 & pH 5.0 \\
\hline \% Concentrate & $34.37 \pm 0.05^{\mathrm{a}}$ & $34.41 \pm 0.19^{\mathrm{a}}$ & $34.55 \pm 0.41^{\mathrm{a}}$ & $33.41 \pm 0.06^{\mathrm{b}}$ \\
\% protein Dumas & $20.923^{\mathrm{a}}$ & $42.324^{\mathrm{b}}$ & $51.594^{\mathrm{c}}$ & $36.57 \pm 0.17^{\mathrm{c}}$ \\
\hline
\end{tabular}

Different letters show statistical difference between the groups $(\mathrm{p}<0.05)$ ANOVA and Tukey's test

Table 2: Content of polyphenols Macadamia

\begin{tabular}{llllll}
\hline Sample & pH 2.0 & pH 3.0 & pH 4.0 & pH 5.0 \\
\% Polyphenols & $256.200 \pm 0.56^{\mathrm{a}}$ & $180.256 \pm 0.56^{\mathrm{b}}$ & $218.230 \pm 0.00^{\mathrm{c}}$ & $367.340 \pm 0.00^{\mathrm{d}}$ & $289.150 \pm 0.00^{\mathrm{e}}$ \\
\hline
\end{tabular}

Different letters show statistical difference between the groups $(\mathrm{p}<0.05)$ ANOVA and Tukey's test

as $70 \pm 80 \%$ of the total seed protein $[19,20]$. Using the SDS-PAGE electrophoresis method with a reductor agent, it was possible to observe globulins and albumins. Albumins present low molecular weight with $11 \mathrm{kDa}$ approximately.

Nuts contain high amounts of vegetable proteins and fatsoluble bioactives as unsaturated fatty acids, phytosterols, phospholipids, phytostanols, essential oils, sphingolipids, tocopherols, tocotrienols, terpenoids, and squalene. Nut seeds are rich in a variety of other nutrients and provide dietary fiber, vitamins (such as folic acid, niacin, vitamin B6, and vitamin E), minerals (such as calcium, magnesium, and potassium), and many other phytochemicals (such as phenolic acids, flavonoids, lignin, hydrolysable tannins, proanthocyanidins, carotenoids, alkaloids, coumestan, and phytates). A healthy diet supplemented with one daily serving of nuts prevents cardiovascular events and possibly the development of other chronic diseases, including Type II diabetes, cancer, high blood pressure, and neurodegenerative diseases. Tree nuts and their co-products (skin or testa, hard shell, green leafy cover, hull, and leaf, among others) are rich sources of phytochemicals that possess multifunction alproperties such as antioxidant activities, anticarcinogenic, antimutagenic effects as well as antiproliferative potential [1,21]. In Macadamia nuts, it has been identified catechol, pyrogallol, and 3,4,5-trihydroxy phenolic compounds and its antioxidant activity in refined oil from Macadamia has been evaluated [22]

The Folin-Ciocalteu's reagent assay is the common method used to determine the total phenolic content (TPC) of nuts. TPCs of nuts, expressed as mg of GAE/100 g of sample, were reported in Phenol-Explorer database $[23,24]$ with a range between 47 and 3673. Chestnut contained the highest TPC (1580-3673 mg GAE/100 g), followed by pecan (1284-2016), walnut (1558-1625), pistachio (867-657), hazelnut (291-835), peanut (0.1-420), almond (47-418), Brazil nut (112-310), cashew (137-274), Macadamia (46-156), and pine nut (32-68). The TPCs of nuts range from 32 to $1650 \mathrm{mg}$ GAE/100 g of sample, with pecan, walnut, and pistachio having the highest values $[25,26]$. In the study reported by Kornsteiner et al. (2006), TPC (expressed as mg of GAE/100 g fresh weight) of nuts decreased in the order of walnut (1625) >pecan (1284) >pistachio (867) > peanut (420) > hazelnut (291) >almond (239) >Brazil nut (112) $>$ Macadamia (46) >pine nut (32). In other studies, it was reported $86 \mathrm{mg} \mathrm{GAE} / 100 \mathrm{~g}$ f sample from skin waste $M$. tetraphylla obtained with aqueous extraction [27]. In this study, the supernatant at $\mathrm{pH} 5.0$ present $367,340 \mathrm{mg}$ GAE $/ 100 \mathrm{~g}$ protein of sample. Due to the above facts previously mentioned, Macadamia protein concentrate can be used as functional ingredients with bioactivity.

\section{ACKNOWLEDGMENTS}

This study was supported by Universidad Técnica de Ambato, Ecuador (Project CPU-1373-2014-UTA) and (Project canje de deuda EspañaEcuador). This work has been reviewed in the English edition by Emilio Labrador. Carrillo W, Dra. Jacqueline Ortiz Doyenne (FCIAL) for support and encouragement.

\section{REFERENCES}

1. Chang SK, Alasalvar C, Bolling BW, Shahidi F. Nuts and their co-products: The impact of processing (roasting) on phenolics, bioavailability, and health benefits - A comprehensive review. J Funct Foods 2016;26:88-122.

2. Ros E. Health benefits of nut consumption. Nutrients 2010;2(7):652-82.

3. Ros E. Nuts and CVD. Br J Nutr 2015;113 Suppl 2:S111-20.

4. Jitngarmkusol S, Hongsuwankul J, Tananuwong K. Chemical compositions, functional properties, and microstructure of defatted macadamia flours. Food Chem 2008;110(1):23-30.

5. Wallace HM. Walton 19 - Macadamia (Macadamia integrifolia, Macadamia tetraphylla and hybrids) A2. In: Yahia EM, editor. Postharvest Biology and Technology of Tropical and Subtropical Fruits. UK: Woodhead Publishing; 2011. p. 450-74e.

6. Dahler JM, McConchie CA, Turnbull CG. Quantifi cation of cyanogenic glycosides in seedlings of three Macadamia (Proteaceae) species. Aust J Bot 1995;43:619-28

7. Navarro SL, Rodrigues CE. Macadamia oil extraction methods and uses for the defatted meal byproduct. Trends Food Sci Technol 2016;54:148-54.

8. Monaghan K. Chemical Composition and Protein Antigenicity-almond (Prunus dulcis) and Macadamia (Macadamia integrifolia) 2008 (PhD Degree Dissertation). Florida: Florida State University.

9. Maro LA, Pio R, Edos SP, Oliveira MC, Prates FC, Lima, LC, et al. Chemical characterization and fatty acids profile in macadamia walnut cultivars. Cienc Rural 2012;42(12):2166-71.

10. INC. Macadamias. In: Nuts and Dried Fruits Nuts and Dried Fruits Global Statistical Review. Reus, Espanha: International Nut and Dried Fruit; 2014. p. 30-3.

11. Laohasongkram $\mathrm{K}$, Mahamaktudsanee $\mathrm{T}$, Chaiwanichsiri $\mathrm{S}$. Microencapsulation of Macadamia oil by spray drying. Proc Food Sci 2011;1:1660-5

12. Vadivel V, Kunyanga CN, Biesalski HK. Health benefits of nut consumption with special reference to body weight control. Nutrition 2012;28(11-12):1089-97

13. Martínez NE, Añón MC. Composition and structural characterization of amaranth protein isolates. An electrophoretic and calorimetric study. J Agric Food Chem 1996;44(9):2523-30

14. Serrano S, Rincón F, García-Olmo J. Cereal protein analysis via Dumas method: Standardization of a micro-method using the Euro vector elemental analyser. J Cereal Sci 2013;58(1):31-6.

15. Laemmli UK. Cleavage of structural proteins during the assembly of the head of bacteriophage T4. Nature 1970;227(5259):680-5.

16. Singleton VL, Rossi JA. Colorimetry of total phenolics with phosphomolybdic-phosphotungstic acid reagents. Am J Enol Vitic $1965 ; 16: 144-58$

17. Lucena ME,Alvarez S, Menéndez C, RieraFA,AlvarezR. $\alpha$-Lactalbumin precipitation from commercial whey protein concentrates. Sep Purif Technol 2007;52(3):446-53.

18. Tavares T, Malcata FX. Whey and whey powders: Protein concentrates and fractions. Encyclopedia of Food and Health. Oxford: Academic Press; 2016. p. 506-13.

19. Marcus JP, Green JL, Goulter KC, Manners JM. A family of antimicrobial peptides is produced by processing of a $7 \mathrm{~S}$ globulin protein in Macadamia integrifolia kernels. Plant J 1999;19(6):699-710.

20. Roux KH, Teuber SS, Sathe SK. Tree nut allergens. Int Arch Allergy Immunol 2003;131(4):234-44.

21. Shahidi F, Ambigaipalan P. Phenolics and polyphenolics in foods, 
beverages and spices: Antioxidant activity and health effects - A review. J Funct Foods 2015;18:820-97.

22. Quinn LA, Tang HH. Antioxidant properties of phenolic compounds in macadamia nuts. J Am Oil Chem Soc 1996;73:1585-9.

23. Rothwell JA, Perez-Jimenez J, Neveu V, Medina-Remón A, M'hiri N, García-Lobato P, et al. Phenol-explorer 3.0: Amajor update of the phenolexplorer database to incorporate data on the effects of food processing on polyphenol content. Database (Oxford) 2013;2013:bat070.

24. Rothwell JA, Urpi-Sarda M, Boto-Ordoñez M, Knox C, Llorach R, Eisner R, et al. Phenol-explorer 2.0: A major update of the phenol-explorer database integrating data on polyphenol metabolism and pharmacokinetics in humans and experimental animals. Database 2012;2012:bas031.

25. Kornsteiner M, Wagner KH, Elmadfa I. Tocopherols and total phenolics in 10 different nut types. Food Chem 2006;98:381-7.

26. Wu X, Beecher GR, Holden JM, Haytowitz DB, Gebhardt SE, Prior RL. Lipophilic and hydrophilic antioxidant capacities of common foods in the United States. J Agric Food Chem 2004;52(12):4026-37.

27. Dailey A, Vuong QV. Optimization of aqueous extraction conditions for recovery of phenolic content and antioxidant properties from Macadamia (Macadamia tetraphylla) skin waste. Antioxidants (Basel) 2015;4(4):699-718. 